\title{
About the Challenged Notion of "Curve of a City": The Example of the Pilgrimage of Lourdes (France)
}

\author{
Olivier Lefebvre \\ Olivier Lefebvre Consultant, Paris, France
}

\begin{abstract}
The French urban planner Marcel Poete set out the notions of "city's curve" and "mysticism" of the city (around the 20 s). The city's curve is the history of the city: In general, there is the beneficial influence of some power, during a long time. And the "mysticism" is when the values of the city are displayed by monuments everywhere. These notions are no more valid. Today the success of a city depends on good governance: The city has to play games in a better way than the rival cities. And the rules of the games are the same everywhere. The "mysticism" is no more fashionable because of two phenomena: (1) the artifying of cities; and (2) what we call the "meaningless and seductive city", referring to the works of Baudrillard (according to him, the disappearance of sense triggers "cool seduction”). Lourdes is an interesting example: The city's curve perfectly explains the past of this city, but not the present. We conclude examining the consequences of the two phenomena concerning these topics: (1) How the artified center of the large cities is fashioned by diverse "historical styles"; and (2) "Airbnbizing" of some cities in Southern Europe.
\end{abstract}

Keywords: historical centre, urban governance, artification, Airbnb

The French city planner Marcel Poete wrote his book Introduction à l'urbanisme (Introduction to Urban Planning) to analyze the processes of the evolution of cities. The goal was "urban art", that is to say, the art of composing the urban landscapes. In some way, he was the French Patrick Geddes (Calabi, 1998). Even if it is uneasy to sum up this rich book, one can retain two main ideas, the "mysticism" of cities and the "city's curve":

(1) The "mysticism" of cities is when an abundance of monuments express (display) the values of these cities. The model is the city of the Hellenistic era, which was beautiful, symmetrical, with the monuments displaying a deep sense of urban life (at least, it is resented in this way, by people in Occidental countries, for centuries).

(2) The city's curve is the evolution of the city during history. The city is a living organism (which is nascent, grows then declines). The explanations given by Poete are subtle and diverse: the road (on lands, on rivers, and on seas), trade, intellectual factors (knowledge), spiritual factors (religion), technology, rivalry of cities, networks of cities, politics... The author plays with the idea that the history of cities is the universal history, the history of the world, or the history of civilization.

Even if today the historians and geographers have made progress in the field of the history of cities, Poete's book deserves attention because the idea of studying the evolution of cities in a systematic way was set

Corresponding author: Olivier Lefebvre, Ph.D., consultant, Olivier Lefebvre Consultant, Paris, France; research fields: communication, information technologies, social space. 
out for the first time. Also, the book attempts to deal with the topic, taking into account the spiritual side (culture, values, and symbols) and the material side (economy). Here, we refer to the book of the French philosopher Castoriadis (The Imaginary Institution of the Society). He argues that in any social phenomenon are implied two ontologies: (1) The "historical/social ontology" concerns the values, the symbols, and finally the "radical imaginary" which ultimately explains and fashions the society (even if it is arbitrary and elusive); and (2) the "ensemblist/identitary ontology", which concerns concrete economic activity (to classify materials, tasks, tools, to count etc.). Any theory concerning the city should take into account the two ontologies. That is why we propose a criticism of Poete's notions ("mysticism" and the "city's curve") which gives a role to the social imaginary, while taking into account the economy.

There are two new phenomena which concern "culture" (the social imaginary) and are compatible with the capitalist economy:

(1) The "artified" city. The centers of the large cities are deeply changed by the artifying of daily life. All the places should be nice décor. Art pervades all the daily life: architecture, fashion, graphical arts, music...

(2) The "meaningless and seductive city". According to the French sociologist Baudrillard, the meaning disappears for several reasons: (a) the TV and the use of replicated reasoning: so simplification and false clarity destroy the meaning; and (b) the manipulation of signs by advertising and propaganda. But the end of meaning is not void; it triggers the "cool seduction" in the consumers' society. "Cool seduction" means vertigo, ecstasy, and inertia. Often, the destruction of the past and the scenarizing in cities trigger destruction of meaning and seduction, both.

The plan of this paper is the following:

(1) We resume the topics of Poete's "mysticism" and "city's curve", criticizing them;

(2) We deal with the example of the pilgrimage of Lourdes (France);

(3) We conclude about the consequences of these new phenomena, artifying of the cities and the "meaningless and seductive city" today.

\section{On the Poete's "Mysticism" of the Cities}

A source of this notion of "mysticism" of the cities is the book of the French historian Fustel de Coulanges, La cité antique (The Ancient City). He insisted on the importance of religion in the ancient Greek and Roman city. He was influential around 1900 in France. But in Occidental countries, one has often imitated the Hellenistic style, at the time of Renaissance, of the French Revolution and the Empire, or in the USA around 1900, at the time of the City Beautiful movement. Indeed, "inspiration" is more relevant than imitation. The French writer André Malraux, in his book Le musée imaginaire (The Imaginary Museum) quotes a story about the famous Italian sculptor Canova. Seeing real ancient Greek statues for the first time (in the British Museum, at London, around 1800), he told: "but it is not that that I have imitated" (Malraux, 1996). In any way, the idea of "mysticism" of the cities leads to a new monumentality which is not fashionable at the time of individualism, consumers' society, and artifying of the city. Indeed, it is half forgotten. For instance, there is a project in Mumbai (India) of building a 100-meter high statue of Shivari ${ }^{1}$.

Another source of the notion of "mysticism" is totality in the works of the French sociologists Durkheim and Mauss. Durkheim studied the rites of totemism in his book Les formes élémentaires de la vie religieuse

\footnotetext{
${ }^{1}$ Shivari was the founder of the Maratha Empire. The capital city was in Pune, in the State of Maharashtra. He struggled against the Mughols, who were Islamic. He was a Hinduist.
} 
(The Elementary Forms of Religious Life). Periodically the people of the clan meet together in long lasting feasts. The goal is to mobilize the energy of the clan, again. It is the "mana". According to Durkheim, the "mana" is the society itself, its totality, the collective meaning of the cosmos, and the life in the clan. It is also the energy of individuals (Durkheim, 2015). Durkheim deals with the question: "Is there something similar in the modern societies?". The answer is that only at the time of the French Revolution (when the Festival of the Supreme Being was organized in Paris), there was something similar. While the French Revolution has not changed Paris very much, one made a plan, the "plan des artistes" ("the artists' plan"), the artists being architects and engineers, according to which Paris would have been covered with monuments, crossed by beautiful "axes", etc. It illustrates the "mysticism" of cities. According to Poete, the Hellenistic city brought political unity, displaying the will of the monarch through many symbols in the city. In the case of the "artists' plan", the values which could have been displayed are progress of man, liberty, independence and greatness of the nation, etc.

Of course, it was not in the intention of Poete to impose values to the populace through symbols displayed in the city. At the opposite, he wanted to know the processes of the evolution of cities to be able to adapt the "urban art" to the spontaneous evolution of the city, avoiding following a dogma.

It is also the argument of the German philosopher Adorno in Jargon of Authenticity: One cannot know that one has to believe. In other words, either one knows, either one believes (Adorno, 2009). An urban planner's doctrine cannot state what the populace has to believe in. Or it evokes the hope of Castoriadis that the "radical imaginary" evolves towards less transcendence and more autonomy.

In any case, the "mysticism" of the city (or the Durkheim's totality) recalls the time when the collective will was imposed to all. It is the opposite of the individualism in the consumers' society.

\section{On the City's Curve}

The idea of a city's curve is no more relevant. From the point of view of economy, a city is a fragment in the spatial division of labor, which concerns the entire world. In the past, some power could generate consensus during a long time, affording stability, therefore success and prosperity. The curve is the history of this power, its successes, and its decline. But now the cities, in competition, play games. Success depends on strategy and chance. The rules of the game are the same everywhere.

One no more speaks of beneficial power, but of efficient governance. The local particularities still exist, but are fashioned in the context of artifying of cities, alongside the same lines, everywhere. The goals are those of the consumers' society: individualism, satisfaction of desires thanks to consumption (the consumers choosing global brands)...

The example of the pilgrimage of Lourdes (France) is useful to show how the notion of city's curve is relevant to explain the past, but not to describe the present.

\section{The Example of the Pilgrimage of Lourdes}

The scheme of the city's curve fits well to explain the city of Lourdes in the past. It is less relevant today. The development of the pilgrimage corresponds to the "revival" of the Catholic Church in the 19th century. Before, there has been another revival, from the time of the Counter Reformation to 1750. It has been perfectly analyzed by the German historian Von Ranke, who is considered as the first modern historian, in History of the Popes: Their Church and States. It is an example of "historical curve", and the causes of which were: (1) the 
strong and canny power of Popes and Jesuits at this time; (2) the initial impetus of the Counter Reformation; (3) a financial strategy, the Popes getting revenue from their states; and (4) a political choice, intervention to defend Catholic religion everywhere it was threatened. The church succeeded in restoring Catholic religion in countries like France, the South of Germany, Poland, and Austria (Von Ranke, 2006).

In the case of Lourdes, all started in 1858, when a young shepherdess saw the Virgin several times. Then the pilgrimage developed quickly, thanks to several factors:

(1) The Assomptionists brought a strong leadership;

(2) It was the start of railways, and books and newspapers diffused the narrative about Lourdes and photos;

(3) The site was well planned. The church bought land, and churches were built. If they are not beautiful (the basilica built in first was criticized by the writer J. K. Huysmans, because of its ugliness), it is integrated in the "collective imaginary" and has become "authentic";

(4) The narrative about Bernadette and miracles thanks to the intervention of the Virgin in Lourdes was a success. A "religious space" was created.

One can define a "religious space". We take into account the ideas of Roger Caillois in L'homme et le sacré (Man and the Sacred) and Durkheim.

A "religious space" involves:

(1) The separation between the "sacred space" and the "secular space". Any contagion from one to the other is prevented. There are "negative rites" according to Durkheim, preventing contact between the two ("lustration rites");

(2) The "sacred space" is planned to allow rites, ceremonies, that is to say, the liturgy;

(3) A narrative allows to make the "sacred space" attractive for believers.

The history of the pilgrimage of Lourdes has been well documented by French authors like Zola and J. K. Huysmans. Also, the sociologist Gabriel Le Bras has studied the evolution of Catholic faith in France at different times.

A first crisis, called "modernist crisis" occurred after the First World War, triggered by quarrels on this topic: What should be the answer of the church, concerning the progress of science, and the changes in the values of society (more and more materialistic and individualist) while the behaviors evolve? An answer was afforded by the philosopher Blondel, in a famous article. His point of view was: To cope with the difficulties caused by a changing world, the church should develop its tradition, which is rich, more than stick to the dogmas. The philosopher proposed to give distinct roles to the church and to the secular institutions: The church has the "speculative" role, that is to say, the values and faith ${ }^{2}$ and the secular institutions are in charge of the material life.

Finally, what happens today?

The narrative is less successful, and the separation sacred/secular is threatened:

(1) Blondel's trade off does not work. The church wanted to let the material life to science. The idea was

\footnotetext{
2 Notice that the distinction speculative/material is not the distinction between "historical/social ontology" and "ensemblist/identitary ontology". The church uneasily accepts the notion of social imaginary. This notion is used by anthropologists and sociologists. For the church, the imagination of human beings is influenced by the true messages of the Christ. The soul is where the good and the evil struggle. But the believers are in a particular situation: They have access to the messages from the Christ and the church, which allow redemption. Adorno is right in opposing believers and thinkers.
} 
that the miracles were checked by doctors. The "Bureau des constatations" ("Office of observations") was created, the mission of which was to present the (possible) miracles (miraculously healed persons) to many doctors, who give their advice. It resulted in the shrinking number of recognized miracles (today, only two in twenty years). As Mgr Perrier (who was the bishop of Lourdes) says in his book Lourdes in History: Church, Culture and Society From 1858 to Today: "all holds together". That is to say: The site and its prestige, the narrative, the miracles, and the pilgrimage itself, all hold together. If the narrative fails, because there are no more frequent miracles (which were seen by the pilgrims and commented), the pilgrimage itself is threatened.

(2) The separation between the "religious space" and the "secular space" becomes blurry. Lourdes is a nice city, in beautiful settings, and attracts tourists. They like the spectacle of the pilgrimage. The contact between sacred and secular, religion and science is meaningless, therefore ... seductive (according to Baudrillard). The contact is triggered by the tourists themselves, and it is a spectacle they like. In some sense, what is called "post catastrophe tourism" (when tourists visit a site after a catastrophe) is the tourism of today: Tourists like the spectacles which are meaningless and seductive. Many cities scenarize the "surprises" which occurred in the past. Paris is fascinating because of the spectacle of many historical surprises: (a) the catastrophic end of the Ancien Régime at the time of the French Revolution and the Empire; (b) the catastrophic end of the Second Empire; (c) the two world wars... Rome can fascinate with the Counter Reformation, its decline at the time of the Age of Enlightment, then the revival in the 19th century, and finally the awkward stakes of today... Lourdes has "only" to display the passage from a secluded village to a prosperous city, the signs of the church's revival in the 19th century and the questions of today... But it is enough to fascinate many tourists.

\section{Conclusions}

In a city, there is always coexistence of the two Castoriadis's ontologies, the "historical/social" and the "ensemblist/identitary". Take the example of Paris, the reader knowing Paris has perhaps noticed that at the metro station Port Royal, one sees two axes crossing one another: (1) an "aesthetic" axis made up of the Observatory, the Fontaine de l'Observatoire, the Luxembourg garden, and the Luxembourg Palace. This axis was part of the "plan des artistes" (Halbwachs, 1920). It is monumental and nice, full of symbols. Also, the streets around the Observatory have been changed at the time of the French Revolution; and (2) a "useful" axis, crossing Paris from the South to the North (Boulevard Saint Michel) dating from the Second Empire. At the time of the Second Empire, the priority was not the embellishment of the city, even if the Opera House, squares, and parks dated from this time ${ }^{3}$. The building of large boulevards was decided by Hausmann just when it became necessary, because of the activities in the quarters that these boulevards linked one another (Halbwachs, $1920)^{4}$. Clearly, the economy was the priority.

What shape does the coexistence of the two ontologies take today?

It is no more Poete's "mysticism" (many monuments displaying the values of the city). The city is no more explained by its "curve" (a strong power makes the city prosperous during a long time). The centers of the large cities are artified. There, the "historical/social" ontology is more visible. In the suburbs and the mid-sized cities, one imitates the centers of the large cities, and the "ensemblist/identitary" ontology is more visible. The

\footnotetext{
${ }^{3}$ Marcel Poete noticed that the Avenue de l'Opéra is without backdrop at the end which is opposite to the Opera House. Or it would be the Hotel du Louvre. A first building was built in 1858 when the world' fair occurred (the hotel was built very quickly, the workers working during the night, thanks to electrical light used for the first time).

${ }^{4}$ However the buildings alongside these boulevards were nicer than the old buildings in the streets remaining unchanged. This has been studied by Halbwachs.
} 
consequence is that people there go to the centers of large cities to benefit from a nice décor, and have fun and entertainment.

The theory of artification has been set out by the French sociologist Nathalie Heinich in the book De l'artification (On Artification). New activities are structured like art (the criteria are existence of critics, exhibitions, museums, recognition of talents, a market, etc.). The artified historical centers of cities mean: whitened facades, parks, squares, fountains, new monuments, or old ones which are revamped, popular brands displayed in smart shops, nice décor ready for "events" of all kinds, etc.

We conclude by two remarks:

There is a role of the meaningless and seductive city.

Take the example of these old churches in the USA which were moved stone by stone, it is not in accordance with what Viollet Le Duc ${ }^{5}$ claimed: The settings of a monument make it nicer. But it is fascinating.

There are several "historical styles" involved in the artifying of cities, like in the Table 1 below.

Table 1

The "Historical Styles" in the Artified Centers of Large Cities

\begin{tabular}{|l|l|l|}
\hline Historical styles & Personalities & Domains \\
\hline History of imitations & Tarde $^{6}$ & History of styles \\
\hline History of aesthetic values & Viollet Le Duc $^{7}$ & Historical truth \\
\hline History of social milieus & Taine $^{7}$ & History of art \\
\hline $\begin{array}{l}\text { History of "surprises" (scenarizing appearance } \\
\text { and disappearance of powers) }\end{array}$ & Baudrillard & Vertigo, mise en abyme, "cool seduction" \\
\hline
\end{tabular}

The meaningless and seductive city is when the contrasts in the past, or the contrasts between past and present, are scenarized. For instance, an ancient backdrop, modern architecture, and contemporary art are displayed (in the same site). Also, the "cool seduction" triggered by meaningless urban landscapes can be felt when one looks at the famous paintings of the Italian painter Giorgio de Chirico. They show odd urban landscapes. They have been often imitated in comics or video games.

In some cities of Southern Europe (Barcelona, cities in the Po Valley in Italy), the inhabitants fear the impact of tourism on their city ${ }^{8}$.

This could be called "Airbnbizing": Old buildings are destroyed, new buildings are built, the rents raise, residents leave the center of the city, traffic grows and the networks are saturated, in some places, the traditional shops are closed and replaced by fast food restaurants, gift shops... It is well known that this phenomenon is at its top in Venice. Inhabitants are aware that tourism has a devastating impact on a city, and that the tourists themselves (who know that tourism is the cause of an upheaval in the city landscape) will accept the change because the meaningless city is also seductive. Of course, the authentic city landscape is lost. But something else appears which is attractive. The flow of tourists should not slow because of its impact on the city landscape. At the opposite, it could grow?

\footnotetext{
${ }^{5}$ Viollet Le Duc is a French architect who sets out a theory on the "historical truth" in architecture.

${ }^{6} \mathrm{He}$ was a French sociologist. He wrote Les lois de l'imitation (Laws of Imitation). According to him, "history is the history of imitations".

${ }^{7}$ He was a French philosopher. According to him, the evolution of art is explained by the diverse social milieus.

${ }^{8}$ In the region of Cinqueterre (several nice villages on the Italian coast, near La Spezia), the flow of tourists is such that quotas are considered.

${ }^{9}$ Even in Paris, some regulation concerning the platforms like Airbnb has been decided.
} 


\section{References}

Adorno, T. (2009). Jargon de l'authenticité (Jargon of authenticity). Paris: Payot.

Baudrillard, J. (1988). De la séduction (On seduction). Paris: Galilée.

Caillois, R. (1993). L'homme et le sacré (Man and the sacred). Paris: Gallimard.

Calabi, D. (1998). Marcel Poete et le Paris des années vingt: origines de l'histoire des villes (Marcel Poete and Paris in the 20s: Origins of history of cities). Paris: L'Harmattan.

Castoriadis, C. (1999). L'institution imaginaire de la société (The imaginary institution of the society). Paris: Seuil.

Durkheim, E. (2015). Les formes élémentaires de la vie religieuse (The elementary forms of religious life). Paris: Garnier.

Halbwachs, M. (1920). Les plans d'extension et d'aménagement de Paris avant le 19 ème siècle (The plans of growth and urban development in Paris before the 19th century). In La Vie Urbaine (The urban life) (pp. 3-28). Paris.

Heinich, N. (2012). De l'artification: enquêtes sur le passage à l'art (On artification: Inquiry on the passage to art). Paris: EHESS.

Malraux, A. (1996). Le musée imaginaire (The imaginary museum). Paris: Gallimard.

Perrier, J. (2015). Lourdes dans l'histoire: Eglise, culture et société de 1858 à nos jours (Lourdes in history: Church, culture and society from 1858 to today). Paris: L'Harmattan.

Poete, M. (2000). Introduction à l'urbanisme (Introduction to urban planning). Paris: Sens et Tonka.

Von Ranke, L. (2006). Histoire de la papauté pendant les seizième et dix-septième siècles (History of the popes during the 16th and 17th centuries). Wroclaw, Poland: Elibron Classics. 